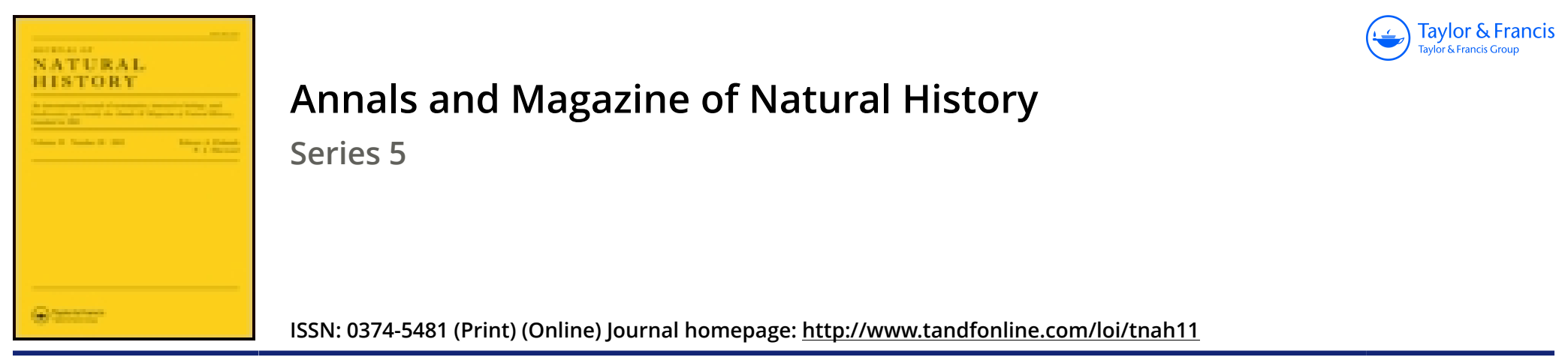

\title{
Notes on the Stomatopoda
}

\section{W.K. Brooks}

To cite this article: W.K. Brooks (1886) Notes on the Stomatopoda, Annals and Magazine of Natural History, 17:98, 166-168, DOI: 10.1080/00222938609460127

To link to this article: http://dx.doi.org/10.1080/00222938609460127

册 Published online: 07 Oct 2009.

Submit your article to this journal

III Article views: 1

Q View related articles $\asymp$ 
of Carbonate of Lime.-Mr. G. Pim exhibited specimens of Spumaria alba, which appears to be unusually abundant this year, as he has received it from Dr. E. P. Wright and MIr. R. M. Barrington, Fassaroe, and had heard of it from near Gorey, \&c. The chief point to which attention was directed was the remarkable incrustation of carbonate of lime, consisting of exceedingly minute needle-shaped crystals which, lying rery frequently more or less at right angles to each other, gave a somewhat cruciform appearance, and were collected into dense matted tufts. Some doubt existing as to the substance being carbonate of lime, Mr. Pim subsequently earefully tested it with acetic acid and oxalate of ammonia, with which it gave the characteristic reaction. The needles seldom exceed $\cdot 0005$ in length by .0001 in width, and are often much less.

Transverse Seations of Halcampa chrysanthellum were exhibited by Prof. Haddon illustrating the arrangement of the muscular bands of the twelve mesenteries, and demonstrating the existence of a pair of very small secondary mesenteries in the alternate mesenterial chambers. The osophagus is ciliated, there are a pair of deep sagittal cesophageal grooves, which are provided with long cilia, and five obscure lateral furrows.

New Alcyonaria.-Dr. E. Perceval Wright exhibited a series of sections through the polyp (decalcified) of Callozostron mirabile, showing the absence of any marked siphonoglyph, the peculiar unfolding of the tentacles, and, at the base of the polyp, the ramifying network of rascular canals.- He further exhibited mounted sections of a new genus and species of the group of the Isidæ, in which the external spicules were like those of a Primnoa. The colony formed a reticulated network. The branches started from the hard joints, and these in the younger twigs were very beantifully ornamented with rows of irregular spine-like processes. The soft joints were very small. The species stands as Acanthoisis flabellum, Wright et Studer.

Micrococcus form (?) on Piper-leaves.-Mr. Archer exhibited some Piper-leaves (given him by Mr. Pim) showing on their lower surface what appeared to be a form of Micrococcus, forming here and there a thin scurfy stratum. If this were referable to that genus it would be a somewhat singular nidus. The leaves did not appear to be injured.

\section{MISCELLANEOUS.}

Notes on the Stomatopoda. By W. K. Broors.

Two species of Stomatopoda are common at Beaufort-Squilla empusa and a Lysiosquilla which, so far as I am aware, has never been described. The swimming-larva of both species are very 
abundant, but I have not succeeded in obtaining the eggs, nor was I able to keep the younger larva alive in confinement, as they all died in moulting, although the older larræ moulted in aquaria. I was therefore compelled to rely upon general resemblances and measurements in my attempts to trace the metamorphosis, although the series were so complete that I believe my results are worthy of confidence.

'The youngest Lysiosquilla larvæ were in the same stage as Claus's larva. This stage is followed by an Erichthus stage, which persists for a number of moults with little change except the increase in size and the gradual acquisition of the appendages.

I have wituessed the change from the last form of this series into the young Lysiosquilla; so it is now certain that the Erichthus type is the larva of this genus, although it is of course possible that other genera may pass through the samo larval stages.

As secondary sexpal characters are rare among the higher Crustacea, it is interesting to note that the female Lysiosiatilla is much larger than the male and of quite a different colour. Fully grown males are from $1 \frac{i}{2}$ to 2 inches in length, while the females are from 3 to 4 inches long. The males are of a grey colour and quite transparent, while the females are more opaque and of a dark olivegreen colour, nearly black.

The babits of our two species are quite different. Lysiosquilla lives in pure sea-sand on beaches which are directly exposed to the ocean swell, and it is very abundant on Bird Shoal and on the seabeach at Fort Macon. It lives in a deep cylindrical vertical burrow, which goes down for sereral feet, and it is almost impossible to procure the animals by digging. The males and females inhabit different burrows, and they lie in wait for prey at the top, which is arched over with sand, so that only the eyes of the animal are exposed. When suitable prey comes within reach they dart out so quickly that the eye can scarcely follow the motion, and, seizing the prey in their large claws, they instantly retreat to the bottom of the burrow, where the food is stored away, and the animal roturns to the mouth of the burrow to resume its watch. They seldom venture more than 3 or 4 inches from the burrow; and I have obtained only one specimen which was captured in the water, although the trawl often brings up an abundant supply of the much larger Squilla empusa.

In constructing its burrow, Lysiosquilla brings up the sand from the bottom by armfuls, which are carried between the large claws to the mouth of the hole, to be deposited as far away as the animal can reach without leaving its burrow.

The burrows are so deep that digging for the animals is almost useless; and after many unsucessful attempts to trap them, I found that it was easy to eatch them by holding a piece of fish or crab near the month of the burrow as a bait with one hand, while the other hand was held ready to cut off the retreat into the burrow, by the use of a tin trowel. Their movements are so very quick that many escaped entirely, while others were cut in two by the trowel, although many were captured alive. 
Squilla empusa lives in hard muddy bottom, in or on the sides of channels where there is a rapid current, and it constructs a shallow U-shaped burrow, open at both ends. The burrow is excavated by the current of water produced by the abdominal appendages, and I have never seen them carrying sand out of the holes. They do not arch over the opening, and they are often found swimming at a distance of many feet from the hole, probably in pursuit of prey.

Squilla stridulates by rubbing the serrated spine of the swimmeret across the serrated ridge on the ventral surface of the telson. The noise which is thus made under water can be clearly heard above the surface.-Johns Hopkins University Circular, Oct. 1885, p. 10.

On the Heart of the Gamasidx and its Significance in the Phylogenetic Consideration of the Acarida and Arachnoidea, and the Classification of the Arthropoda. By Prof. Care Clads.

The heart, discovered by M. Willibald Winkler, which has hitherto remained entirely unknown in the group Acarida, occurs in the posterior region of the body and above the rectum; it pulsates strongly and rapidly. It is remarkably liko the heart of the Daphnidæ, and like this is reduced to a single chamber, which is perforated on each side by a fissure furnished with lip-like valves and passes anteriorly into an elongated median aorta. The position towards the posterior end of the body, which is rather surprising at the first glance, is explained by the simplification which the abdomen of the mite has undergone, appearing as a comparatively short unsegmented region, united without any demarcation with the cephalothorax. Hitherto the heart has been demonstrated only in Gamasus, and it is probable that its occurrence may be confined to only a few families of the Acarida, perhaps to the Gamasidæ alone. It is best seen in all its parts in the six-legged larvæ (probably of Gamasus fucorum, De G.), in which the integument is comparatively thin. These have probably never previously been examined in the living state under a high power, or the presence of the quickly pulsating heart could not easily bave escaped observation. But even through the less transparont skin of the adult animal the heart is not difficult to recognize when one has seen it in the more delicate larva.

In the unilocular heart of Gamasus we have evidently to do with a retrograde organ. Just as Claus regarded the similar heart in the Cladocera as a secondary simplified form derived from the manychambered heart of the Phyllopoda, this simple heart in the Mites, with its single pair of fissures, may be regarded as an abbreviated and rudimentary spider's heart, the latter being of elongated tubular form, with three pairs of fissures, and connected with a complex system of arterial vessels. And just as, among the Entomostraca, the unilocular heart of the Ostracoda and Copepoda occurs only in particular families of those orders and is altogether wanting in the lower groups, so in the Acarida the lower families, such as tho 